\title{
Physicochemical characteristics of garlic (Allium sativum L.) shoots from different areas in Namhae
}

\author{
Hwan-Sik Yoon, Min-Jung Kang, Cho-Rong Hwang, Hye-jin Sim, Gyeong-Min Kim, \\ Jung-Hye Shin* \\ Namhae Garlic Research Institute, Namhae 668-812, Korea
}

\section{남해지역 마늘종의 이화학적 특성}

\author{
윤환식 · 강민정 · 황초롱 · 심혜진 · 김경민 · 신정혜* \\ (재) 남해마늘연구소
}

\begin{abstract}
This paper introduces the physicochemical characteristics of garlic shoots investigated in the 8 areas of Namhae, Gohyeon-myeon (GHM), Nam-myeon (NM), Samdong-myeon (SDM), Namhae-eup (NHE), Seo-myeon (SM), Seolcheon-myeon (SCM), Idong-myeon (IDM) and Changsoen-myeon (CSM). The moisture was 80.15 \pm 0.37 $\sim 83.87 \pm 0.15 \mathrm{~g} / 100 \mathrm{~g}$. The crude protein and lipid were $1.59 \pm 0.02 \sim 2.25 \pm 0.09 \mathrm{~g} / 100 \mathrm{~g}$ and $0.35 \pm 0.01 \sim 0.48 \pm 0.03$ $\mathrm{g} / 100 \mathrm{~g}$, respectively. Ash was $0.65 \pm 0.03 \sim 0.71 \pm 0.03 \mathrm{~g} / 100 \mathrm{~g}$. In addition, the total levels of phenol and flavonoid were searched as $33.02 \pm 1.78 \sim 58.41 \pm 1.08 \mathrm{mg} / 100 \mathrm{~g}$ and $11.60 \pm 3.36 \sim 23.95 \pm 2.04 \mathrm{mg} / 100 \mathrm{~g}$, respectively. The garlic shoots in IDM, where the highest total chlorophyll level detected as $170.58 \pm 1.04 \mu \mathrm{g} / \mathrm{g}$ and in CSM, where the lowest total chlorophyll level investigated as $116.65 \pm 0.00 \mu \mathrm{g} / \mathrm{g}$, were unveiled. The mineral elements (S, Ca, Fe, $\mathrm{K}$, Mg, Na, Mn and Zn) were analyzed by ICP-OES, and $\mathrm{K}$ was the most highly contained mineral with 7257.0 $\pm 87.9 \sim 10070.0 \pm 9.7 \mathrm{mg} / \mathrm{kg}$. Significant feature of garlic shoots in IDM and NHE was that the total amounts of mineral were relatively higher than other regions as $21,143.5 \mathrm{mg} / \mathrm{kg}$ and $20,581.2 \mathrm{mg} / \mathrm{kg}$, respectively. The cultivating regions were revealed as the one of important matters with the level of allicin $(\mathbf{7 8 . 0 3} \pm 6.15 \sim 203.43 \pm 18.47 \mathrm{mg} / \mathrm{kg})$. In particular, the level of allicin of garlic raised in SDM $(203.43 \pm 18.47 \mathrm{mg} / \mathrm{kg})$ was approximately 2.2 2.6 times higher than those in CSM $(92.86 \pm 8.70 \mathrm{mg} / \mathrm{kg})$ and SCM $(78.03 \pm 6.15 \mathrm{mg} / \mathrm{kg})$. The sulfur compounds content of diallyl trisulde was remarkably higher, especially the garlic shoots in IDM with $830.62 \pm 14.69 \sim 1281.10 \pm 27.71 \mathrm{mg} / \mathrm{kg}$.
\end{abstract}

Key words : garlic shoots, mineral, allicin, sulfur compounds

\section{서 론}

마늘의 학명은 Allium sativum Linnaeus로서 백합과 (Lilliaceae) 파속(Allium)에 속하며 형태적, 생리적 특성에 따라 분류되고 이용되어 왔다(1). 인편의 크기에 따라 대인 편종과 소인편종, 구를 둘러싸는 보호엽의 색에 따라서 백 색종, 담갈 또는 담백색종, 담자색 그리고 자색종으로 구분 되며, 추대 방식에 따라 완전추대, 불완전추대, 불추대종으 로 구분하기도 한다(2). 국내 마늘은 생육지역의 기후특성 에 따라 따뜻한 남부지역인 제주, 남해, 해남, 무안 등에서

*Corresponding author. E-mail : whanbee@hanmail.net Phone : 82-55-860-8947 Fax : 82-55-860-8960
재배되는 난지형(暖地型) 마늘과 상대적으로 추운 중부 지 방인 의성, 서산, 삼척 등에서 재배되는 한지형(寒地型) 마늘 로 구분되며 대부분 완전추대종으로 구근을 발육시키기 위해서는 5월 초순경부터 마늘종(蒜薹)을 뽑아주거나 제거 해야 한다(3)

마늘종은 마늘의 줄기 안쪽 속대가 발달한 것으로 마늘 과 유사하게 함황화합물을 지니고 있으며, 클로로필, 식이 섬유, 비타민류 등의 함량이 마늘구에 비해 더 높아 마늘과 성분이 유사하면서도 차별화되는 성분들이 함유되어 있을 것으로 추정되며 마늘에 비하여 매운맛이나 향이 약하여 식용이 용이하다는 장점(4)이 있고, 마늘종으로부터 분리 된 플라보노이드들은 항산화 활성을 지니고 있음이 보고 
(5,6)되어 있어 기능성 식품소재로서 충분한 활용 가능성이 제시되고 있다. 마늘이 DNA 손상억제 작용(7), 돌연변이 유발억제 작용(8), 항암효과(9), 콜레스테롤 저하작용(10), 혈당저하효과(11), 간 조직 보호작용(12), 항균작용( $(13,14)$, 항산화작용(15-18) 등 다양한 생리활성이 있음이 보고되어 있으므로, 동체에서 생산되는 마늘종도 이와 유사한 효능 들을 가질 것으로 기대된다.

마늘종은 마늘 재배에 따른 부가 생산물로 2010년을 기 준으로 볼 때 남해군 전체의 마늘 생산액(600억원) 대비 $1 / 6$ 을 차지하는데, 전체 생산량은 3,500 톤 정도이다. 마늘이 수확, 손질, 건조 등 수확이후 수매까지 상당한 노동력을 요구함을 감안할 때 마늘종은 수확기 1 2주 사이에 상당한 수입을 확보할 수 있는 장점을 지니고 있다. 하지만 유통되 는 마늘종은 대부분 마늘종 볶음, 장아찌, 무침 등의 부식 원료로 사용되고 있으며, 별다른 활용방안이 없어 그 소비 가 한정되고 있다. 마늘종의 가공법으로는 장기간 저장을 위하여 소금물이나 간장, 고추장에 담구어 장아찌류로 가 공하는 방법이 활용되고 있으나 이 외 가공법은 거의 없다. 따라서 일시 출하에 따른 가격 지지기반이 전무하며, 그 활용도나 부가가치는 매우 낮은 실정이다. 또한, 관련된 연구도 미진하여 마늘종의 특성을 홍보할 수 있는 근거도 부족하므로 이와 관련한 기초 데이터의 확보가 요구되고 있다. 따라서 본 연구에서는 마늘종의 성분과 생리활성 규 명에 대한 연구를 통하여 마늘종의 품질특성에 대한 기초 자료를 제공하고자 한다.

\section{재료 및 방법}

\section{실험재료}

본 실험에 사용한 마늘종은 2013년 경남 남해군(고현면, 남면, 삼동면, 남해읍, 서면, 설천면, 이동면, 창선면)에서 재배된 것을 각 지역별 산지 위판장에서 동일 일자에 수거 하였다. 각각의 마늘종은 흐르는 물에 세척하여 물기를 제 거 한 것을 실험 직전에 분쇄하여 시료로 사용하였다.

\section{일반성분}

수분함량은 분쇄한 시료 약 $1.0 \mathrm{~g}$ 을 취하여 적외선 수분 측정기(MB 25, OHAUS, Nanikon, Switzerland)로 측정하였 으며 조단백, 조지방, 회분은 $\mathrm{AOAC}$ 방법(19)에 준하여 분석 하였다. 즉, 조단백질은 Kjeldahl 질소정량법, 조지방은 Soxhet 추출법, 조회분은 직접 회화법으로 분석하였다.

\section{총 페놀 화합물의 함량}

총 페놀 함량은 마늘종 추출물에 동량의 Foline-ciocalteau 시약을 혼합하여 3 분간 반응시킨 후 $10 \% \mathrm{Na}_{2} \mathrm{CO}_{3}$ 용액을 넣어 진탕한 다음 실온의 암실에서 1 시간 반응시켜
spectrophotometer(Libra S35, Biochrome Ltd., Cambridge, England)로 $700 \mathrm{~nm}$ 에서 시료 무첨가구를 대조로 하여 흡광 도를 측정하였다(20). Gallic acid(Sigma Co., St. Louis, MO, USA)로부터 얻은 표준 검량곡선으로부터 시료 추출물 중 총 페놀 함량을 산출하였다.

\section{플라보노이드 함량}

플라보노이드 함량은 시료액 $1 \mathrm{~mL}$ 에 $10 \%$ aluminum nitrate, $1 \mathrm{M}$ potassium acetate 및 에탄올을 각 $1 \mathrm{~mL}$ 씩 차례로 가하여 잘 혼합하고 상기와 동일한 방법으로 반응시켜 415 $\mathrm{nm}$ 에서 흡광도를 측정하였다(21). Quercetin(Sigma Co.)을 표준물질로 하여 얻은 검량선에 따라 플라보노이드 화합물 의 함량을 계산하였다.

\section{클로로필 함량}

클로로필 함량은 시료 $5 \mathrm{~g}$ 에 $80 \%$ 아세톤을 가해 $50 \mathrm{~mL}$ 로 만들어 추출하고 여과(Whatman No. 2)한 여액을 시료로 사용하여 $645 \mathrm{~nm}$ 와 $663 \mathrm{~nm}$ 에서 흡광도를 측정한 다음 아래 의 계산식에 의해 산출하였다(22).

Chlorophyll $\mathrm{a}(\mathrm{mg} / \mathrm{L})=12.72 \times \mathrm{O} . \mathrm{D}_{663}-2.58 \times$ O. $\mathrm{D}_{645}$ Chlorophyll b $(\mathrm{mg} / \mathrm{L})=22.88 \times 0_{0 . D_{645}}-5.50 \times 0 . D_{663}$

Total chlorophyll $(\mathrm{mg} / \mathrm{mL})=7.22 \times$ O.D $_{663}+20.3 \times$ O.D $_{645}$

\section{무기물 함량}

무기물 함량은 식품공전 방법(23)에 준하여 측정하였다. 균일하게 마쇄한 마늘종 $1 \mathrm{~g}$ 을 마이크로웨이브용 teflon vessel에 칭량하고 질산(70\%) $10 \mathrm{~mL}$ 를 가한 다음 hood내에 서 4시간동안 정치시켜 예비 분해 한 후 microwave digestion system (QWAVE 1000, Questron Technologies Corp., Mississauga, ON, Canada)을 이용하여 분해하였다. 분해된 액에 증류수를 가하여 $25 \mathrm{~mL}$ 로 정용한 다음 여과지 로 여과한 후 시험용액으로 사용하였다. 시험용액 중 $\mathrm{S}$, $\mathrm{Ca}, \mathrm{Fe}, \mathrm{K}, \mathrm{Mg}, \mathrm{Na}, \mathrm{Mn}$ 및 $\mathrm{Zn}$ 은 ICP-OES (Optima 7300DV, Perkin-Elmer Co., Shelton, CT, USA)를 이용하여 측정하였 다. 이때, RF power는 $1300 \mathrm{~W}$, plasma argon gas flow rate $15 \mathrm{~L} / \mathrm{min}$, auxiliary argon gas flow rate $0.2 \mathrm{~L} / \mathrm{min}$, nebulizer argon gas flow rate $0.6 \mathrm{~L} / \mathrm{min}$ 으로 하였다.

\section{알리신 및 황화합물의 함량}

알리신과 황화합물의 분석을 위해 균일하게 마쇄한 마늘 종 $10 \mathrm{~g}$ 에 hexane $50 \mathrm{~mL}$ 를 가하여 30 분간 진탕 추출한 후 여과한 여액을 회전증발농축기로 완전 건고하였다. 이 것을 hexane $2 \mathrm{~mL}$ 로 재용해하여 $0.22 \mu \mathrm{m}$ membran filter로 여과 후 GC (Clarus 600, PerkinElmer Co.)로 분석하였으며 분석용 컬럼은 Elite-5(Crossbond 5\% diphenyl-95\% dimethyl polysiloxane, $30 \mathrm{~m} \times 0.25 \mathrm{~mm}(\mathrm{id}) \times 0.25 \mathrm{um}(\mathrm{df})$, PerkinElmer 
Co.)를 이용하였으며 주입구 및 검출기 온도는 각각 $220^{\circ} \mathrm{C}$ 및 $250^{\circ} \mathrm{C}$ 로 유지하였다. 이때 분석조건으로 알리신은 오븐 온도 $40^{\circ} \mathrm{C}$ 에서 1 분간 유지 후 분당 $3{ }^{\circ} \mathrm{C}$ 씩 상승시킨 후 $140^{\circ} \mathrm{C}$ 에서 5 분간 유지하여 분석하였으며 황화합물은 오븐 온도를 $40^{\circ} \mathrm{C}$ 에서 1 분간 유지한 후 분당 $3^{\circ} \mathrm{C}$ 씩 상승시키면서 $70^{\circ} \mathrm{C}$ 에서 3 분간 유지하다가 분당 $5^{\circ} \mathrm{C}$ 씩 상승시켜 $160^{\circ} \mathrm{C}$ 에 서 5 분간 유지하면서 분석하였다. 알리신(ChromaDex Inc., Irvine, CA, USA) 및 황화합물(Sigma Co.)은 표준 검량곡선 으로부터 시료 추출물 중의 함량을 산출하였다.

\section{통계처리}

실험결과는 3 5회 반복 실험한 결과로부터 평균치와 표 준편차(means $\pm \mathrm{SD})$ 로 나타내었으며 통계분석은 SPSS 12.0 package program software(SPSS Inc., Chicago, IL, USA)를 이용하여 Duncan's multiple range test에 의해 시료간의 유 의적 차이 $(\mathrm{p}<0.05)$ 를 검정하였다.

\section{결과 및 고찰}

\section{일반성분}

수분, 조단백, 조지방 및 회분의 함량을 측정한 결과 (Table 1), 수분은 $80.15 \pm 0.37 \sim 83.87 \pm 0.15 \mathrm{~g} / 100 \mathrm{~g}$ 의 범위였 으며, 조단백은 창선면 마늘종에서 $2.25 \pm 0.09 \mathrm{~g} / 100 \mathrm{~g}$ 으로 가장 높았고 나머지 마늘종에서는 $1.59 \pm 0.02 ~ 1.92 \pm 0.07$ $\mathrm{g} / 100 \mathrm{~g}$ 의 범위였다. 조지방은 $0.35 \pm 0.01 \sim 0.48 \pm 0.03 \mathrm{~g} / 100$ $\mathrm{g}$ 의 범위였는데 고현면, 남면, 삼동면 지역의 마늘종이 0.42 $\mathrm{g} / 100 \mathrm{~g}$ 으로 함량이 동일하였고, 이동면 지역 마늘종이 $0.48 \pm 0.03 \mathrm{~g} / 100 \mathrm{~g}$ 으로 조지방 함량이 가장 높았다. 회분은 $0.65 \pm 0.03 \sim 0.73 \pm 0.02 \mathrm{~g} / 100 \mathrm{~g}$ 의 범위였다.

Table 1. Total phenol and flavonoid contents of garlic shoots from different areas in Namhae

\begin{tabular}{ccccc}
\hline Sample code $^{1)}$ & Moisture & Crude protein & Crude lipid & Ash \\
\hline GHM & $\left.82.11 \pm 0.09^{\mathrm{ab} 2}\right)$ & $1.74 \pm 0.06^{\mathrm{ab}}$ & $0.42 \pm 0.04^{\mathrm{a}}$ & $0.69 \pm 0.04^{\mathrm{ab}}$ \\
NM & $82.54 \pm 0.17^{\mathrm{dd}}$ & $1.61 \pm 0.04^{\mathrm{a}}$ & $0.42 \pm 0.01^{\mathrm{a}}$ & $0.69 \pm 0.01^{\mathrm{ab}}$ \\
SDM & $80.15 \pm 0.37^{\mathrm{a}}$ & $1.92 \pm 0.07^{\mathrm{c}}$ & $0.42 \pm 0.01^{\mathrm{a}}$ & $0.65 \pm 0.03^{\mathrm{a}}$ \\
NHE & $83.87 \pm 0.15^{\mathrm{e}}$ & $1.69 \pm 0.16^{\mathrm{a}}$ & $0.35 \pm 0.01^{\mathrm{a}}$ & $0.70 \pm 0.02^{\mathrm{ab}}$ \\
SM & $82.37 \pm 0.26^{\mathrm{c}}$ & $1.74 \pm 0.08^{\mathrm{ab}}$ & $0.35 \pm 0.01^{\mathrm{a}}$ & $0.70 \pm 0.06^{\mathrm{ab}}$ \\
SCM & $82.89 \pm 0.22^{\mathrm{d}}$ & $1.86 \pm 0.08^{\mathrm{bc}}$ & $0.39 \pm 0.01^{\mathrm{a}}$ & $0.71 \pm 0.03^{\mathrm{ab}}$ \\
IDM & $81.73 \pm 0.21^{\mathrm{b}}$ & $1.59 \pm 0.02^{\mathrm{a}}$ & $0.48 \pm 0.03^{\mathrm{b}}$ & $0.70 \pm 0.03^{\mathrm{ab}}$ \\
CSM & $82.41 \pm 0.49^{\mathrm{cd}}$ & $2.25 \pm 0.09^{\mathrm{d}}$ & $0.46 \pm 0.02^{\mathrm{ab}}$ & $0.73 \pm 0.02^{\mathrm{b}}$ \\
\hline
\end{tabular}

${ }^{11}$ GHM; Gohyeon-myeon, NM; Nam-myeon, SDM; Samdong-myeon, NHE; Namhae-eup, SM; Seo-myeon, SCM; Seolcheon-myeon, IDM; Idong-myeon, CSM; Changsoen-myeon.

2)ae All values are mean \pm standard deviation $(\mathrm{n}=5)$, means in the column with different superscripts are significantly different by Duncan's multiple range test at $\mathrm{p}<0.05$.
남해군 지역 마늘종의 일반성분은 수분함량이 $81.73 \%$ 이상 이며 조단백, 회분, 조지방 순으로 함량이 높았다.

마늘의 수분함량은 중국(69.7\%), 태안(66.4\%), 제주 (63.0\%), 의성(62.8\%), 남해(60.2\%), 단양 $(57.4 \%)$ 순으로 높 고 조단백 함량은 $7.3 \sim 5.9 \%$ 범위이며, 조지방 함량은 0.9 1.0\% 범위라는 보고(6)와 비교해볼 때, 현재 남해 8개 지역의 마늘종은 마늘에 비해 수분의 함량은 높고, 조단백 및 조지방의 함량은 다소 낮았는데 이는 상대적인 수분 차이에 기인한 것으로 생각된다.

\section{총페놀 및 플라보노이드 함량}

페놀화합물은 구조적으로 phenolic hydroxyl기를 가지기 때문에 단백질 및 기타 거대 분자들과 쉽게 결합하며, 항산 화, 항암 등의 다양한 생리활성을 가진다(24). 남해군 지역 별 마늘종의 총페놀 및 플라보노이드 함량을 분석한 결과는 Table 2와 같다.

마늘종의 총페놀 함량은 재배지역에 따라 차이를 나타내

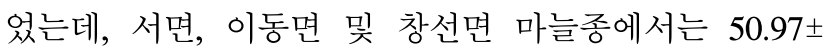
$1.91 \sim 58.41 \pm 1.08 \mathrm{mg} / 100 \mathrm{~g}$ 으로 여타 지역산에 비해 유의적 으로 높은 함량이었고, 고현면, 남면, 삼동면과 남해읍 마늘 종에서 $33.02 \pm 1.78 \sim 37.52 \pm 2.63 \mathrm{mg} / 100 \mathrm{~g}$ 으로 유의적으로 낮은 함량이었다. 플라보노이드 함량은 삼동면, 설천면, 이 동면 및 창선면 마늘종이 $21.65 \pm 1.11 ~ 23.95 \pm 2.04 \mathrm{mg} / 100$ $\mathrm{g}$ 의 범위로 유의적으로 높은 함량이었고, 타지역산에서는 $16 \mathrm{mg} / 100 \mathrm{~g}$ 미만으로 낮은 함량이었다.

Table 2. Total phenol and flavonoid contents of garlic shoots from different areas in Namhae

\begin{tabular}{ccc} 
& & $(\mathrm{mg} / 100 \mathrm{~g})$ \\
\hline Sample code $^{1)}$ & Total phenol & Flavonoid \\
\hline GHM & $\left.35.26 \pm 0.4 \mathrm{a}^{\mathrm{ab} 2}\right)$ & $11.60 \pm 3.36^{\mathrm{a}}$ \\
NM & $37.52 \pm 2.63^{\mathrm{b}}$ & $15.96 \pm 0.71^{\mathrm{b}}$ \\
SDM & $36.85 \pm 1.25^{\mathrm{ab}}$ & $23.91 \pm 0.26^{\mathrm{c}}$ \\
NHE & $33.02 \pm 1.78^{\mathrm{a}}$ & $13.87 \pm 2.38^{\mathrm{ab}}$ \\
SM & $50.97 \pm 1.91^{\mathrm{d}}$ & $13.48 \pm 3.49^{\mathrm{ab}}$ \\
SCM & $41.67 \pm 2.59^{\mathrm{c}}$ & $21.65 \pm 1.11^{\mathrm{c}}$ \\
IDM & $58.41 \pm 1.08^{\mathrm{e}}$ & $23.95 \pm 2.04^{\mathrm{c}}$ \\
CSM & $51.41 \pm 3.69^{\mathrm{d}}$ & $22.44 \pm 0.32^{\mathrm{c}}$ \\
\hline
\end{tabular}

${ }^{1)}$ Sample code are referred to Table 1 .

${ }^{2) a e}$ All values are mean \pm standard deviation ( $n=5$ ), means in the column with different superscripts are significantly different by Duncan's multiple range test at $p<0.05$.

Chung과 $\operatorname{Kim}(25)$ 의 연구에 의하면 건조한 마늘종의 총 페놀 함량은 $29.2 \sim 32.8 \mathrm{mg} / 100 \mathrm{~g}$ 이고, 생마늘의 총페놀 함 량은 한지형과 난지형에서 각각 $33.7 \pm 0.8 \mathrm{mg} / 100 \mathrm{~g}$ 과 $32.8 \pm 0.9 \mathrm{mg} / 100 \mathrm{~g}$ 이라고 보고되어 있는데, 본 연구 결과에 서는 남해산 마늘종의 총페놀 함량은 $33.02 \pm 1.78$ 
$58.41 \pm 1.08 \mathrm{mg} / 100 \mathrm{~g}$ 의 범위로 이들의 결과와 유사하거나 더 높은 함량으로 항산화, 항암 등 다양한 생리활성을 가질 가능성이 높을 것으로 사료된다.

\section{클로로필 함량}

마늘종 중의 클로로필 $\mathrm{a}$ 와 클로로필 $\mathrm{b}$ 함량을 각각 측정 하고 총 클로로필 함량으로 계산한 결과는 Table 3 과 같다. 남해 8 개 지역의 마늘종 중 클로로필 $\mathrm{a}$ 의 함량은 고현면, 남면, 설천면 및 이동면 마늘종에서 101.58 $\pm 1.18 ~ 126.06$ $\pm 0.39 \mu \mathrm{g} / \mathrm{g}$ 으로 타 지역산에 비해 유의적으로 높은 함량이 었고, 삼동면 마늘종이 $87.60 \pm 0.29 \mathrm{\mu g} / \mathrm{g}$ 으로 가장 낮은 함량 이었다. 클로로필 b는 남면산과 이동면 마늘종에서 각각 $41.50 \pm 0.18 \mu \mathrm{g} / \mathrm{g}$ 과 $44.52 \pm 1.15 \mathrm{\mu g} / \mathrm{g}$ 으로 유의적으로 높은 함량이었으며, 그 외 지역산에서는 31.92 $\pm 0.0 ~ 38.06 \pm 1.14$ $\mu \mathrm{g} / \mathrm{g}$ 으로 정량되었다. 총클로로필의 함량은 이동면 마늘종 에서 $170.58 \pm 1.04 \mathrm{\mu g} / \mathrm{g}$ 으로 가장 높았고, 창선면 마늘종에 서 $116.65 \pm 0.00 \mathrm{\mu g} / \mathrm{g}$ 으로 가장 함량이 낮았다.

클로로필은 식물체에 존재하면서 광합성에 관여하는데, 자연계에는 많은 종류의 클로로필 및 유사물질이 분포하고 있다. 클로로필 a는 정제하면 청흑색의 왁스 상태인 고체로 얻어지며 용액은 청록색이고, 클로로필 $\mathrm{b}$ 는 왁스상태인 고 체는 녹흑색을 띠며 용액은 황녹색을 띤다. 식물에 널리 분포되어 있는 천연 녹색색소인 클로로필은 광선이 차단된 상태에서는 유리라디칼 소거제로 작용하여 지방질의 자동 산화를 방지하는 생리작용이 규명되어 있다(26,27).

Table 3. Chlorophyll contents of garlic shoots from different areas in Namhae

\begin{tabular}{cccc}
\hline Sample code & & $(\mu \mathrm{g} / \mathrm{g})$ \\
\hline GHM & Chlorophyll-a & Chlorophyll-b & Total chlorophyll \\
NM & $101.58 \pm 1.18^{\mathrm{e} 2)}$ & $38.06 \pm 1.14^{\mathrm{c}}$ & $139.64 \pm 0.04^{\mathrm{d}}$ \\
SDM & $112.08 \pm 1.03^{\mathrm{g}}$ & $41.50 \pm 0.18^{\mathrm{d}}$ & $153.58 \pm 1.21^{\mathrm{e}}$ \\
NHE & $97.60 \pm 0.29^{\mathrm{a}}$ & $36.85 \pm 0.50^{\mathrm{b}}$ & $124.45 \pm 0.79^{\mathrm{b}}$ \\
SM & $95.53 \pm 0.63^{\mathrm{c}}$ & $36.81 \pm 0.32^{\mathrm{b}}$ & $127.85 \pm 0.42^{\mathrm{c}}$ \\
SCM & $104.64 \pm 0.29^{\mathrm{f}}$ & $32.69 \pm 0.28^{\mathrm{a}}$ & $128.22 \pm 0.36^{\mathrm{c}}$ \\
IDM & $126.06 \pm 0.30^{\mathrm{b}}$ & $44.52 \pm 1.15^{\mathrm{e}}$ & $140.65 \pm 0.79^{\mathrm{d}}$ \\
CSM & $87.73 \pm 0.00^{\mathrm{b}}$ & $31.92 \pm 0.00^{\mathrm{a}}$ & $116.58 \pm 1.04^{\mathrm{f}}$ \\
\hline
\end{tabular}

${ }^{1)}$ Sample code are referred to Table 1.

2)ath All values are mean \pm standard deviation $(\mathrm{n}=5)$, means in the column with different superscripts are significantly different by Duncan's multiple range test at $p<0.05$.

\section{무기물 함량}

마늘종에서 8종의 무기물 함량을 분석한 결과(Table 4), 무기물 총량은 이동면과 남해읍에서 재배된 마늘종에서 각각 $21,163.7 \mathrm{mg} / \mathrm{kg}$ 과 $20,608.3 \mathrm{mg} / \mathrm{kg}$ 으로 타 지역산에 비해 높은 함량이었고, 남면산에서 $15,870.3 \mathrm{mg} / \mathrm{kg}$ 으로 함
량이 가장 낮았으며 고현면, 삼동면, 설천면, 창선면 마늘종 간에는 유의적인 차이가 없었다.

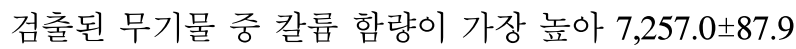
$\sim 10,070.0 \pm 19.7 \mathrm{mg} / \mathrm{kg}$ 이었고, 다음으로 황이 $5,190.0 \pm 20.0$ $\sim 8,194.0 \pm 30.2 \mathrm{mg} / \mathrm{kg}$ 의 범위로 함유되어 있었으며, 칼슘은 $1,463.0 \pm 7.0 \sim 2,109.0 \pm 10.2 \mathrm{mg} / \mathrm{kg}$ 으로 다량 함유되어 있었 다. 그 외 철, 망간, 아연은 $35.0 \mathrm{mg} / \mathrm{kg}$ 미만으로 미량 함유되 어 있어 마늘종 중의 무기물 함량은 무기물의 종류에 따라 함량에 대차가 있음을 확인할 수 있었다.

무기물 중 나트륨 함량은 고현면, 서면, 설천면 및 창선면 지역에서 생산된 마늘종에서 $100 \mathrm{mg} / \mathrm{kg}$ 이하로 낮은 반면 남면, 남해읍, 이동면 지역 마늘종에서는 209.8 6.2 356.3 $\pm 4.0 \mathrm{mg} / \mathrm{kg}$ 으로 높은 함량이었다. 미량성분으로 성장기에 필수적인 영양소인 아연은 $16.2 \pm 0.2 ~ 34.8 \pm 0.1 \mathrm{mg} / \mathrm{kg}$ 의 범 위로 삼동면 마늘종에서 가장 높았다.

Chang과 Lee(28)는 마늘의 무기성분은 수확시기와 생산 지역에 따라 차이가 있다고 하였으며, Lee 등(29)은 $\mathrm{pH}$, 유기물 함량 및 무기성분 등 토양 특성과 마늘의 품질특성 간에 상관성이 있다고 보고한 바 있다. 본 연구에서도 지역 별 마늘종의 무기물 조성비율 및 함량이 서로 차이를 보인 것은 무기질 비료의 사용량과 주변환경 및 토양조건 등과 같은 환경요인에 기인한 것으로 사료된다.

\section{알리신 함량}

마늘의 풍미성분은 무색, 무취의 alliin (S-allyl-cysteinesulfoxide)이 물리적 손상을 받아 세포가 파괴될 때 cysteine sulfoxide lyase (allinase)라는 효소의 작용을 받아 allicin, pyruvate 및 ammonia를 생성한다(30). Allicin은 마늘의 독 특한 풍미로서 마늘의 저장이나 가공 중 중요한 품질지표가 될 수 있으나 매우 불안정한 상태로 존재하기 때문에 보통 allicin의 구조상 결합물질인 유황성분을 측정하거나 최종 분해물질인 ammonia나 pyruvic acid를 측정하기도 한다 (31).

남해군 관내 지역별 마늘종의 알리신 함량은 Table 5 에 나타낸 바와 같이 재배 지역에 따라 함량 차이가 컸는데,

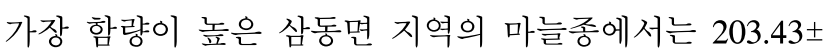
$18.47 \mathrm{mg} / \mathrm{kg}$ 이었으나, 가장 함량이 낮은 설천면 및 창선면 지역 마늘종에서 알리신 함량이 각각 $78.03 \pm 6.15 \mathrm{mg} / \mathrm{kg}$, $92.86 \pm 8.70 \mathrm{mg} / \mathrm{kg}$ 으로 함량 차는 2.2 2.6배 였으며, 이외 지역의 마늘종에서 알리신은 $100 \mathrm{mg} / \mathrm{kg}$ 이상 함유되어 있 었다.

마늘의 알리신 함량은 한지형과 난지형에서 각각 $33.5 \pm 0.8 \mathrm{mg} / 100 \mathrm{~g}$ 및 $33.2 \pm 0.7 \mathrm{mg} / 100 \mathrm{~g}$ 이며, 생마늘종의 알리신 함량은 한지형과 난지형에서 각각 $28.2 \pm 0.9$, $26.1 \pm 1.0 \mathrm{mg} / 100 \mathrm{~g}$ 으로 마늘보다 낮았다고 보고(24)되어 있다. 
Table 4. Mineral contents of garlic shoots from different areas in Namhae

$(\mathrm{mg} / \mathrm{kg})$

\begin{tabular}{ccccccccc}
\hline \multirow{2}{*}{ Minerals } & \multicolumn{7}{c}{ Sample code $^{\mathrm{l})}$} \\
\cline { 2 - 8 } & GHM & NM & SDM & NHE & SM & SCM & IDM & CSM \\
\hline S & $6351.0 \pm 30.5^{\mathrm{C} 2)}$ & $5190.0 \pm 20.0^{\mathrm{a}}$ & $6678.0 \pm 32.5^{\mathrm{d}}$ & $8194.0 \pm 30.2^{\mathrm{g}}$ & $7388.0 \pm 47.0^{\mathrm{e}}$ & $6120.0 \pm 13.6^{\mathrm{b}}$ & $8135.0 \pm 26.8^{\mathrm{f}}$ & $6687.0 \pm 18.1^{\mathrm{d}}$ \\
$\mathrm{Ca}$ & $1735.0 \pm 7.4^{\mathrm{e}}$ & $2109.0 \pm 10.2^{\mathrm{h}}$ & $1495.0 \pm 3.7^{\mathrm{b}}$ & $2075.0 \pm 6.8^{\mathrm{g}}$ & $1626.0 \pm 4.4^{\mathrm{c}}$ & $1709.0 \pm 6.0^{\mathrm{d}}$ & $1860.0 \pm 9.5^{\mathrm{f}}$ & $1463.0 \pm 7.0^{\mathrm{a}}$ \\
$\mathrm{Fe}$ & $28.9 \pm 0.4^{\mathrm{f}}$ & $30.1 \pm 0.4^{\mathrm{g}}$ & $25.6 \pm 0.1^{\mathrm{d}}$ & $26.8 \pm 0.2^{\mathrm{e}}$ & $19.5 \pm 0.2^{\mathrm{a}}$ & $20.8 \pm 0.3^{\mathrm{b}}$ & $26.9 \pm 0.1^{\mathrm{e}}$ & $24.2 \pm 0.1^{\mathrm{c}}$ \\
$\mathrm{K}$ & $8804.0 \pm 52.6^{\mathrm{c}}$ & $7257.0 \pm 87.9^{\mathrm{a}}$ & $8900.0 \pm 23.7^{\mathrm{d}}$ & $9164.0 \pm 11.1^{\mathrm{e}}$ & $9930.0 \pm 34.5^{\mathrm{f}}$ & $8684.0 \pm 0.9^{\mathrm{b}}$ & $10070.0 \pm 19.7^{\mathrm{g}}$ & $8857.0 \pm 33.0^{\mathrm{cd}}$ \\
$\mathrm{Mg}$ & $844.7 \pm 3.9^{\mathrm{d}}$ & $901.2 \pm 8.3^{\mathrm{f}}$ & $734.7 \pm 1.2^{\mathrm{a}}$ & $872.1 \pm 4.4^{\mathrm{e}}$ & $835.4 \pm 1.8^{\mathrm{c}}$ & $834.6 \pm 2.9^{\mathrm{c}}$ & $827.2 \pm 7.6^{\mathrm{c}}$ & $810.6 \pm 4.1^{\mathrm{b}}$ \\
$\mathrm{Na}$ & $77.7 \pm 2.6^{\mathrm{c}}$ & $356.3 \pm 4.0^{\mathrm{g}}$ & $135.9 \pm 0.8^{\mathrm{d}}$ & $236.5 \pm 3.5^{\mathrm{f}}$ & $63.9 \pm 1.2^{\mathrm{b}}$ & $83.2 \pm 1.7^{\mathrm{c}}$ & $209.8 \pm 6.2^{\mathrm{e}}$ & $47.6 \pm 2.0^{\mathrm{a}}$ \\
$\mathrm{Mn}$ & $8.6 \pm 0.0^{\mathrm{b}}$ & $8.4 \pm 0.1^{\mathrm{a}}$ & $17.0 \pm 0.0^{\mathrm{h}}$ & $12.8 \pm 0.1^{\mathrm{f}}$ & $12.1 \pm 0.0^{\mathrm{e}}$ & $9.2 \pm 0.1^{\mathrm{c}}$ & $14.6 \pm 0.0^{\mathrm{g}}$ & $11.8 \pm 0.1^{\mathrm{d}}$ \\
$\mathrm{Zn}$ & $29.3 \pm 0.3^{\mathrm{g}}$ & $18.3 \pm 0.2^{\mathrm{b}}$ & $34.8 \pm 0.1^{\mathrm{h}}$ & $27.1 \pm 0.2^{\mathrm{f}}$ & $23.0 \pm 0.1^{\mathrm{d}}$ & $24.4 \pm 0.5^{\mathrm{e}}$ & $20.3 \pm 0.2^{\mathrm{c}}$ & $16.2 \pm 0.2^{\mathrm{a}}$ \\
\hline Total & $17,879.2$ & $15,870.3$ & $18,021.0$ & $20,608.3$ & $19,897.8$ & $17,485.2$ & $21,163.7$ & $17,917.5$ \\
\hline
\end{tabular}

${ }^{11)}$ Sample code are referred to Table 1 .

${ }^{2) a-h}$ All values are mean \pm standard deviation $(n=3)$, means in the row with different superscripts are significantly different by Duncan's multiple range test at $p<0.05$.

Table 5. Allicin contents of garlic shoots from different areas in Namhae

\begin{tabular}{cc} 
& \\
\hline Sample code $^{\mathrm{l})}$ & $(\mathrm{mg} / \mathrm{kg})$ \\
\hline GHM & $111.40 \pm 8.74^{\mathrm{bc} 2}$ \\
NM & $134.79 \pm 10.81^{\mathrm{d}}$ \\
SDM & $203.43 \pm 18.47^{\mathrm{e}}$ \\
NHE & $122.20 \pm 12.99^{\mathrm{cd}}$ \\
SM & $102.31 \pm 7.38^{\mathrm{bc}}$ \\
SCM & $78.03 \pm 6.15^{\mathrm{a}}$ \\
IDM & $107.67 \pm 10.10^{\mathrm{bc}}$ \\
CSM & $92.86 \pm 8.70^{\mathrm{ab}}$ \\
\hline
\end{tabular}

${ }^{1)}$ Sample code are referred to Table 1 .

${ }^{2) a+}$ All values are mean \pm standard deviation $(n=3)$, means in the column with different superscripts are significantly different by Duncan's multiple range test at $p<0.05$.

\section{황화합물 함량}

마늘종 중의 황화합물 분석을 위하여 ethyl disulfide, methyl disulfide, propyl sulfide, diallyl disulfide, propyl disulfide 및 diallyl trisulfide를 분석한 결과 모든 시료에서 methyl disulfide를 제외한 5종의 황화합물만이 검출되었으 며, 그 결과는 Table 6과 같다. 마늘종 중 함황화합물은 diallyl trisulfide의 함량이 월등히 높았는데, 이동면 마늘종 에서 $427.03 \pm 27.72 \mathrm{mg} / \mathrm{kg}$ 으로 가장 높았고, 남해읍과 설천 산 마늘종에서는 각각 $276.87 \pm 14.70 \mathrm{mg} / \mathrm{kg}$ 과 $294.43 \pm 51.99$ $\mathrm{mg} / \mathrm{kg}$ 으로 타지역산에 비해 유의적으로 낮은 함량이었다. 다음으로 diallyl disulfide가 69.51 $\pm 1.76 ~ 121.97 \pm 14.60$ $\mathrm{mg} / \mathrm{kg}$ 으로 함량이 높았고, 이어 propyl disulfide, ethyl disulfide 및 propyl sulfide의 순이었다. Diallyl disulfide는 서면, 설천면, 이동면 및 창선면 지역 마늘종에서는 100 $\mathrm{mg} / \mathrm{kg}$ 이상이었으나, 그 외 시료에서는 $69.51 \pm 1.76$ $85.87 \pm 2.56 \mathrm{mg} / \mathrm{kg}$ 으로 그 함량이 낮았다. Propyl disulfide는

Table 6. Sulfur compound contents of garlic shoots from different areas in Namhae

\begin{tabular}{|c|c|c|c|c|c|c|}
\hline Sample code ${ }^{1)}$ & Ethyl disulfide & Propyl sulfide & Diallyl disulfide & Propyl disulfide & Diallyl trisulfide & Total \\
\hline GHM & $12.38 \pm 3.95^{-22)}$ & $1.77 \pm 0.00^{\mathrm{abc}}$ & $85.87 \pm 2.56^{\mathrm{ab}}$ & $31.91 \pm 1.98^{b}$ & $330.20 \pm 38.85^{\mathrm{ab}}$ & 462.13 \\
\hline NM & $15.28 \pm 4.51^{\mathrm{abc}}$ & $1.74 \pm 0.01^{\mathrm{ab}}$ & $69.51 \pm 1.76^{\mathrm{a}}$ & $27.12 \pm 2.27^{\mathrm{a}}$ & $319.72 \pm 3.96^{\mathrm{ab}}$ & 433.37 \\
\hline SDM & $16.63 \pm 1.81^{\mathrm{abc}}$ & $1.76 \pm 0.05^{\mathrm{ab}}$ & $84.05 \pm 3.62^{a b}$ & $32.52 \pm 1.96^{\mathrm{bc}}$ & $359.40 \pm 20.58^{b}$ & 494.36 \\
\hline $\mathrm{NHE}$ & $20.10 \pm 5.75^{\mathrm{c}}$ & $1.77 \pm 0.03^{\mathrm{abc}}$ & $71.38 \pm 6.13^{\mathrm{a}}$ & $26.75 \pm 0.76^{a}$ & $276.87 \pm 14.70^{a}$ & 396.87 \\
\hline SM & $14.69 \pm 0.64^{\mathrm{abc}}$ & $1.80 \pm 0.04^{\mathrm{bc}}$ & $100.93 \pm 6.28^{\mathrm{bc}}$ & $31.02 \pm 1.25^{\mathrm{b}}$ & $374.76 \pm 33.68^{\mathrm{bc}}$ & 523.2 \\
\hline $\mathrm{SCM}$ & $14.91 \pm 0.85^{\mathrm{abc}}$ & $1.73 \pm 0.01^{\mathrm{a}}$ & $121.97 \pm 14.60^{\mathrm{d}}$ & $32.72 \pm 2.62^{\mathrm{d}}$ & $294.43 \pm 51.99^{\mathrm{a}}$ & 465.76 \\
\hline IDM & $13.49 \pm 0.60^{\mathrm{ab}}$ & $1.83 \pm 0.04^{\mathrm{c}}$ & $102.41 \pm 14.55^{\mathrm{bc}}$ & $43.67 \pm 1.56^{\mathrm{bc}}$ & $427.03 \pm 27.72^{c}$ & 588.43 \\
\hline CSM & $19.53 \pm 3.21^{\mathrm{bc}}$ & $1.79 \pm 0.02^{\mathrm{abc}}$ & $114.52 \pm 17.07^{\mathrm{cd}}$ & $36.35 \pm 3.61^{c}$ & $337.02 \pm 48.15^{\mathrm{ab}}$ & 509.21 \\
\hline
\end{tabular}

\footnotetext{
${ }^{11}$ Sample code are referred to Table 1.

2)add All values are mean \pm standard deviation $(\mathrm{n}=3$ ), means in the column with different superscripts are significantly different by Duncan's multiple range test at $\mathrm{p}<0.05$.
} 
$26.75 \pm 0.76 \sim 33.67 \pm 1.56 \mathrm{mg} / \mathrm{kg}$ 의 범위였고, propyl sulfide 는 $1.73 \pm 0.01 \sim 1.83 \pm 0.04 \mathrm{mg} / \mathrm{kg}$ 의 범위로 시료간의 차이가 적었다.

분석되어진 함황화합물 총량은 이동면 지역 마늘종에서 $588.43 \mathrm{mg} / \mathrm{kg}$ 으로 가장 높았으며, 남해읍 지역 마늘종에서 는 $396.87 \mathrm{mg} / \mathrm{kg}$ 으로 가장 함량이 낮았다. 함황화합물의 종류와 함량 차이는 재배되는 지역의 환경에 따라 달라지는 것으로 추정된다.

동결건조 마늘에서 총 32 종의 휘발성 유기성분이 검출되 었는데, 이 중 황화합물이 21종, aldehyde 류가 4종, alcohol 류와 ester류는 각 2종씩, 기타화합물 3종이 확인되었으며, 주요 화합물로는 diallyl trisulfide( $36.58 \%$ ), diallyl disulfide (35.82\%), allyl methyl trisulfide(5.98\%) methyl propyl trisulfide(2.64\%) 등이 알려져 있다(6). 본 연구 결과 마늘종 의 황화합물은 diallyl trisulfide가 약 $70 \%$, diallyl disulfide가 약 $18.0 \%$ 를 차지하고 있어 마늘의 함황화합물과 비교할 때 이들 두 화합물이 주요 함황화합물임은 동일하나 그 함량의 범위는 서로 상이함을 알 수 있었다.

\section{요 약}

마늘종의 주요 성분 함량에 대한 기초자료를 확보하고자 마늘의 주산지인 남해군 8개 지역에서 마늘종을 수거하여 비교 분석하였다. 수분은 $80.15 \pm 0.37 \sim 83.87 \pm 0.15 \mathrm{~g} / 100 \mathrm{~g}$, 조단백 및 조지방은 각각 $1.59 \pm 0.02 ~ 2.25 \pm 0.09 \mathrm{~g} / 100 \mathrm{~g}$ 및 $0.35 \pm 0.01 \sim 0.48 \pm 0.03 \mathrm{~g} / 100 \mathrm{~g}$ 이었으며 회분은 $0.65 \pm 0.03$ $0.71 \pm 0.03 \mathrm{~g} / 100 \mathrm{~g}$ 이었다. 총페놀 및 플라보노이드 함량은 각각 $33.02 \pm 1.78 \sim 58.41 \pm 1.08 \mathrm{mg} / 100 \mathrm{~g}$ 과 $11.60 \pm 3.36 \sim 23.95$ $\pm 2.04 \mathrm{mg} / 100 \mathrm{~g}$ 이었다. 총 클로로필 함량은 이동면 지역의 마늘종에서 $170.58 \pm 1.04 \mathrm{\mu g} / \mathrm{g}$ 으로 가장 높았고 창선면 지역 의 마늘종은 $116.65 \pm 0.00 \mu \mathrm{g} / \mathrm{g}$ 으로 가장 낮았다. 무기물은 총 8종이 검출되었으며, 검출된 무기물 중 칼륨(7257.0 $\pm 87.9 \sim 10070.0 \pm 9.7 \mathrm{mg} / \mathrm{kg}$ )의 함량이 가장 높았고, 총량은 이동면과 남해읍 지역의 마늘종이 각각 $21,163.7 \mathrm{mg} / \mathrm{kg}$ 과 $20,608.3 \mathrm{mg} / \mathrm{kg}$ 으로 타 지역산에 비해 높은 함량이었다. 알리신 함량은 $78.03 \pm 6.15 ~ 203.43 \pm 18.47 \mathrm{mg} / \mathrm{kg}$ 으로 재배 지역에 따라 함량 차이가 컸으며, 함황화합물 5 종을 분석한 결과 diallyl trisulfide가 약 $70 \%$ 로 가장 함유 비율이 높았는 데, 이동면 지역 마늘종에서 $427.03 \pm 27.72 \mathrm{mg} / \mathrm{kg}$ 으로 가장 높은 함량이었다. 이상의 결과를 종합하여 볼 때 지리적 환경이 유사한 남해군내 8 개 지역에서 재배된 마늘종의 성분간 함량 차이는 시비량, 일조량 등의 재배 환경과 재배 품종 및 재배기술에 의한 것으로 추정되며, 마늘종 재배지 역간의 함량차이는 있으나 마늘의 유효물질을 함유하고 있어 식품소재로서 활용 가치가 우수할 것으로 판단된다.

\section{References}

1. Kim MB, Oh YG, Lim SB (2009) Physicochemical characteristics of garlic from daejeong Jeju and major cultivation areas in Korea. Korean J Culin Res, 15, 59-66

2. Etoh T (1985) Studies on the sterility in garlic, $A$ sativum L. Mem Fac Argic Kagoshima Univ, 21, 77-132

3. Jo JS (1990) Food materials. Gijeunyungusa, Seoul, p 154-155

4. Chung, JY, Kim CS (2008) Antioxidant activities of domestic garlic (Allium sativum L.) stems from different areas. J Korean Soc Food Sci Nutr, 37, 972-978

5. Kim MY, Choi SW, Chung SK (2000) Antioxidative flavonoids from the garlic (Allium sativum L.) shoot. Food Sci Biotechnol, 9, 199-203

6. Kim MY, Kim YC, Chung SK (2005) Identification and in vitro biological activities of flavonols in garlic leaf and shoot: inhibition of soybean lipoxygenase and hyaluronidase activities and scavenging of free radicals. J Sci Food Agric, 85, 633-640

7. Park PS, Lee MY (1992) The effects of onion and garlic on copper-phenanthroline complex induced DNA degradation. J Korean Soc Food Nutr, 21, 367-371

8. Kim SH, Kim JO, Lee SH, Park KY, Park HJ, Chung HY (1991) Antimutagenic compounds identified from the chloroform fraction of garlic (Allium sativum). J Korean Soc Food Nutr, 20, 253-259

9. Rho SN, Han JH (2000) Cytotoxicity of garlic and onion methanol extract on human lung cancer cell lines. J Korean Soc Food Sci Nutr, 29, 870-874

10. Sheo HJ (1999) Effects of garlic on the blood lipids and other serum components in rats. J Korean Soc Food Sci Nutr, 28, 1339-1348

11. Jain RC, Vyas CR (1975) Garlic in alloxan-induced diabetic rabbits. Am J Clin Nutr, 28, 6865-6874

12. Kim HJ, Kim GJ, Jun TW, Lee ES, Lee YS, Han OK (2002) Hepatoprotective effects of semisulcospira libertina and garlic on the liver damage induced by carbon tetrachloride in rats. J Korean Soc Food Sci Nutr, 31, 58-520

13. Chung KS, Kim JY, Kim YM (2003) Comparison of antibacterial activities of garlic juice and heat-treated garlic juice. Korean J Food Sci Technol, 35, 540-543

14. Kim MH, Kim SY, Shin WS, Lee JS (2003) Antimicrobial activity of garlic juice against Escherichia coli O157:H7. Korean J Food Sci Technol, 35, 752-755

15. Nuttakaan L, Viboon R, Nantaya C, Janusz MG (2006) 
Quantitative evaluation of the antioxidant properties of garlic and shallot preparations. Nutrition, 22, 266-274

16. Iqbal S, Bhanger MI (2005) Stabilization of sunflower oil by garlic extract during accelerated storage. Food Chem, 100, 246-254

17. Yang SY, Yu SO, Kim TC, Kim BW, Park YJ, Cho JY, Kim YM, Heo BG (2005) Compare to the component contents and anti-oxidation activities between Goheung native garlic variety and introductions. J Korean Soc Plant People Environ, 8, 1-5

18. Lee EJ, Kim KS, Jung HY, Kim DH, Jang HD (2005) Antioxidant activities of garlic (Allium sativum L.) with growing districts. Food Sci Biotechnol, 14, 123-130

19. AOAC (1990) Official Methods of Analysis. 13th ed. Association of Official Analytical Chemists, Washington, DC, USA, p132

20. Gutfinger T (1981) Polyphenols in olive oils. J Am Oil Chem Soc, 58, 966-968

21. Moreno MIN, Isla MI, Sampietro AR, Vattuone MA (2000) Comparison of the free radical scavenging activity of propolis from several regions of Argentina. J Ethnopharmacol, 71, 109-114

22. Son SG, Je SM, Woo SY, Byun KO, Kang YJ, Kwang BS (2006) Physiological differences of Ilex rotunda and Illicium anisatum under low light intensities. J Agric Forest Meteorol, 8, 61-67

23. Korea Food and Drug Administration (2013) Food code. KFDA, Seoul, Korea 10-1-65

24. Lee SO, Lee HJ, Yu MH, Im HG, Lee IS (2005) Total poly phenol contents and antioxidant activities of methanol extracts from vegetables produced in Ullung island. Korean J Food Sci Technol, 37, 233-240

25. Chung JY, Kim CS (2009) Antioxidant activities of domestic garlic (Allium sativum L.) stems and garlic bulbs according to cooking methods. J Korean Soc Food Sci Nutr, 38, 188-194

26. Tanielian C, Wolff C (1988) Mechanism of physical quenching of singlet molecular oxygen by chlorophylls and related compounds by biological interest. Photochem Photobiol, 48, 277-280

27. Jeon HY, Kim JK, Seo DB, Lee SJ (2009) Effect of chlorophyll a on UVB-induced cellular responses and type I pN collagen synthesis in vitro. Korean J Food Sci Technol, 41, 700-705

28. Chang KM, Lee MS (1999) A study on mineral contents of the underground vegetables produced in Korea harvested in different times. Korean J Soc Food Sci, 15, 545-549

29. Lee YK, Sin HM, Woo KS, Hwang IG, Kang TS, Jeong HS (2008) The relationship between functional quality of garlic and soil composition. Korean J Food Sci Technol, 40, 1-5

30. Shwimmer S, Guadagni GD (1961) Ralation between olfactory threshold concentration and pyruvate acid content of onion juice. J Food Sci, 94, 97-100

31. Shwimmer S, Wentrom DW, Guadagni GD (1964) Relation between pyruvate content and odor strength of reconstituted onion powder. Food Technol, 18, 121-124

(접수 2014년 3월 4일 수정 2014년 5월 15일 채택 2014년 5월 29일) 